\title{
MUDr. Michael Želízko, CSc., se v letošním roce dožívá 60 let
}

MUDr. Michael Želízko absolvoval 1. lékařskou fakultu Karlovy univerzity v Praze, promoval $\checkmark$ roce 1985. Po studiu (a již během studia) pracoval v neurofyziologické laboratoři 3. lékařské fakulty Karlovy univerzity v Praze. V roce 1987 se přihlásil do konkurzu na 2. interní výzkumnou základnu IKEM. V té době jsem odcházel z IKEM a tehdejší přednosta Juraj Fabián si mě zavolal a ptal se na MUDr. Michaela Želízko, kterého, a jeho manželku, jsem v té době znal. Tehdy jsem netušil, jak velkou službu jsem české intervenční kardiologii svým velmi pozitivním vyjádřením vykonal.

MUDr. Michael Želízko se v IKEMu od počátku věnoval invazivní a intervenční kardiologii v celé její širiri a postupně se podílel na zavádění nejnovějších intervenčních metod na pracovišti IKEM a v rámci spolupráce tehdejší Pracovní skupiny invazivní a později i intervenční kardiologie a nynější České asociace intervenční kardiologie pomáhal výrazně v rozšíření nejmodernějších intervenčních metod v rámci celé České republiky. Podílel se výraznou měrou i na organizaci edukačních kurzů intervenční kardiologie, a to jak na evropské úrovní - např́klad setkáním Evropského bifurkačního klubu v Praze v roce 2008 nebo $v$ rámci pěti ročníků PRAGUE WORKSHOP ON CORONARY STENTING s vysOce kvalitní mezinárodní účastí. Brzy po nástupu do IKEMu se stal vedoucím lékařem oddělení intervenční kardiologie a spolu s ostatními svými spolupracovníky se podílel na tom, že toto oddělení po celou dobu udržovalo prioritu v oboru, a to nejen v rámci České republiky. Své zkušenosti velmi intenzivně, ale i extenzivně, předával v rámci celé řady workshopů organizovaných v IKEM a, jakjiž bylo uvedeno, Pracovní skupinou intervenční kardiologie - podílel se celkem na 15 těchto workshopech.

Měl jsem čest dělat mu oponenta při jeho úspěšné obhajobě kandidátské disertační práce na téma Primární koronární angioplastika v akutní fázi infarktu myokardu s elevací úseku ST a tato práce dokumentovala, že MUDr. Michael Želízko, CSc., se jako jeden z prvních podílel na zavedení této velmi úspěšné léčebné metody v rámci České republiky a potažmo i predáváním zkušeností nejen do států Evropské unie.

Jako jedni z prvních zavedli právě díky Michaelu Želízkovi v IKEMu program Primární koronární plastiky u akutního infarktu myokardu, v roce 1993 se podílel na zavedení implantací koronárních stentů, které výrazným způsobem ovlivnilo úroveň revaskularizace myokardu a výrazně se podílel (měl jsem tu čest s ním v této oblasti spolupracovat) i na prosazení úhrady lékových stentů pro co nejvíce pacientů při intervenční léčbě koronární nemoci. Osobně se domnívám, že právě zásluhou MUDr. Michaela Želízka je dnes lékový stent i v České republice implantován v naprosté většině léčených nemocných. $\vee$ rámci výzkumného úkolu ministerstva zdravotnictví jsem měl možnost s Michaelem spolupracovat i při zavádění perkutánních implantací aortálních chlopní a byl to právě Michael Želízko, který v České republice v roce 2008 provedl první perkutánní implantaci aortální chlopně. Je rovněž jeho výraznou zásluhou, že tato další extrémně úspěšná metoda se začala ex-
MUDr. Michael Želízko, CSc

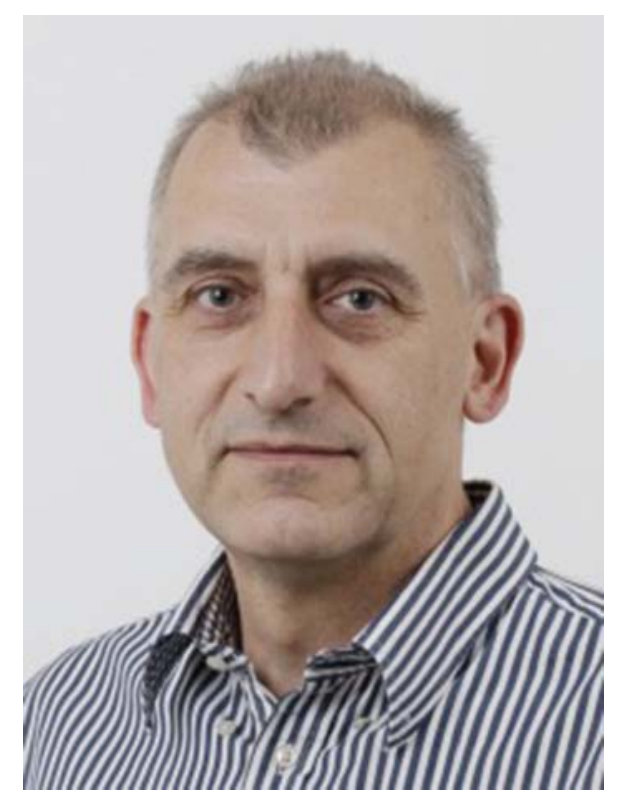

tenzivněji rozšiřovat v rámci České republiky. Vedle vedení oddělení intervenční kardiologie v IKEMu pracoval Michael Želízko jako náměstek ředitele IKEM pro léčebně preventivní péči, ve své odbornosti vykonával funkci místopředsedy a později i předsedy Pracovní skupiny intervenční kardiologie a na príští volební období byl znovu zvolen prezidentem České asociace intervenční kardiologie.

MUDr. Michael Želízko, CSc., se výrazně podílel i na popularizaci moderních metod intervenční kardiologie u laické veřejnosti.

Milý Michaeli, za redakční radu časopisu Intervenční a akutní kardiologie si Ti dovoluji popřát ještě mnoho let aktivní odborné činnosti, mnoho štěstí v osobním životě a všechno nejlepší. Jan F. Vojáček 